\title{
Knitting the Web of Leadership Styles and Strategies on Service Delivery and Economic Wellbeing of Citizens in the Nigerian Fourth Republic
}

\author{
Matthew Funsho Bello, PhD \\ Department of Public Administration \\ Faculty of Arts and Social Sciences \\ Gombe State University \\ Gombe. Nigeria
}

$\&$

Kajo Aondohemba Emmanuel

Department of Business Administration

University of Abuja

Received: Dec. 22, 2020 Accepted: Mar. 30, 2021 Online published: Apr. 8, 2021

doi:10.5296/jpag.v11i2.18517～URL: https://doi.org/10.5296/jpag.v11i2.18517

\begin{abstract}
This study centres on the Nigerian experience in leadership styles and strategies in the $21^{\text {st }}$ century. This study covers 1999-2020. The population of the study is the entire staff of the 43 Federal Ministries in Abuja, Nigeria. The sample size was two hundred and thirty-six (236) respondents. The study adopted both primary and secondary sources of data, correlation and regression analysis were used to determine the existing relationship using SPSS Package. The findings revealed that a positive relationship exists between leadership styles and strategies and service delivery to citizens, but not significant in achieving service delivery with the standard error of 1.240 , and a p-value of 0.387 which is greater than $0.05(5 \%)$ level of significance. The second finding also reveals that, there is a positive relationship between leadership styles and strategies and the economic wellbeing of citizens in Nigeria but not significant in achieving the economic wellbeing of citizens with the standard error of 2.312, and a p-value of 0.673 which is greater than $0.05(5 \%)$ level of significance. The study concluded that, the different leadership styles and strategies to be adopted are based on the
\end{abstract}


prevailing situation the leader finds him or herself. The study recommended that government should from time to time organize leadership seminars and workshops for leaders at all levels both in the public and private sectors with a view to educating them on the need for quality leadership and the provision of service delivery for citizens' wellbeing in the $21^{\text {st }}$ century in Nigeria.

Keywords: leadership styles, strategies, $21^{\text {st }}$ century, service delivery, economic wellbeing

\section{Introduction}

In every setting be it private or public, there must exist an arrowhead that is saddled with the responsibilities of planning, directing and controlling the operational affairs of such setting. Such arrowheads are often sometimes celebrated or booed for the successes or failures of such organizations as the case may be. The head as the case may be is the "leader," and to many, leaders are born, not made. It is tremendously accepted, however, that to be a good leader, one must practically have basically the experience, knowledge, commitment, patience, and most importantly, the skill to negotiate and work with others to achieve goals. Leadership is arguably one of the most observed, yet least understood phenomena on earth (Burns, in Abbasialiya, 2010). Over time, researchers have proposed many different styles of leadership as there is no particular style of leadership that can be considered universal. No matter the styles of leadership, however, a good or effective leader must inspire, motivate and direct activities to help achieve group or organizational goals. Conversely, an ineffective leader does not contribute to organizational progress and can, in fact, detract from organizational goal accomplishment. According to Naylor (1999), effective leadership is a product of the heart and an effective leader must be visionary, passionate, creative, flexible, inspiring, innovative, courageous, imaginative, experimental and initiates change.

Nigeria as a country got its independence in the year 1960, and has since been governed by many leaders. The leadership trends and experiences cut across civilian and military rule which were either dictatorial or democratic in nature and character. There is so much that can be written about the leadership situation in Nigeria but for the purpose of this study, we shall focus our attention on the Fourth Republic which is from 1999 to date. Leadership involves a type of responsibility aimed at achieving particular ends by applying the available resources (human and material) and ensuring a cohesive and coherent organization in the process (Ololube, 2013). Northouse (2007) and Rowe (2007) described leadership as a process whereby an individual influences a group of individuals to achieve a common goal.

This study is anchored on the premise that every leader of a country adopts a style of leadership so desired and most appropriate in the world for certain reasons. The litany of leadership in Nigeria can be sequentially traced since President Obasanjo Olusegun's reign as a democratically elected leader in (1999-2006). The leadership style of President Umaru Musa Yar'Adua (2007-2010) and the leadership style of Goodluck Jonathan which was immediately after the demise of the President Yar'Adua on the $5^{\text {th }}$ May, 2010. He led from (2010-2015). Also, the style of leadership embraced by the incumbent leader President Muhammadu Buhari from May $29^{\text {th }}, 2015$ to date. 
The study considered the strategic contributions of Nigerian leadership styles from 1999 to 2020 and also examined the impact of the styles and strategies and where this has led the country to. The researchers adopted in the study other theoretical debates and empirical reviews of other writers and also suggested the styles and best strategies for effective and efficient leadership in the present-day Nigeria. Nigeria as a nation is said to be a multilingual state, blessed with several tribes, cultures and traditions. A casual observer will say without fear of contradiction that, there are leadership problems in the country which are manifested in both the public sector, and private section. These problems manifest themselves in forms of organizational politics, power tussle, insubordination, indecision, tribalism, suppression, nepotism, corruption, insecurity, etc. Besides, lack of conceptual clarity of the term "leadership style and strategies" to be adopted while in power is the kernel of these problems. For instance, when an organization fails to achieve its objectives, the employees will blame the leaders in some cases. In other cases, when an organization fails, the leader blames the employees. But this should not be the case. The success or failure of an organization is supposed to be shared by variables/factors of leadership namely: the leader, the followers and the situation/environment. In addition, leaders without the appropriate strategies and strategies still will scramble for a leadership position without a clear vision in Nigeria and when given the opportunity to lead, they rather lead in the company of cabals. When people who lack the skill, knowledge and abilities become leaders of a country, they will not be able to practically adopt appropriate leadership styles and strategies in pursuit of national objectives. This has often led to a low standard of living of citizens, insecurity, decayed infrastructure, unemployment, harsh economic policies, and unfriendly business environment etc. The cumulative effect of all these will lead to economic hardship and poverty.

The main objective of the study is to knit together the leadership styles and strategies in the Nigerian Fourth Republic and to see the effect of this on service delivery and by extension, the economic wellbeing of the Nigerian populace. The specific objectives are:

a. To examine whether the leadership styles and strategies adopted in Nigeria have led to service delivery considered to be crucial to the Nigerian citizens in the $21^{\text {st }}$ century.

b. To determine whether a change in the different leadership styles and strategies (autocratic, laissez-faire, democratic, transactional and transformational) and service delivery (economic wellbeing) of the Nigerian citizens in the $21^{\text {st }}$ century.

For the purpose of this study, the following null research hypotheses were formulated:

$\mathbf{H o}^{1}$ There is no significant relationship between leadership styles and strategies adopted in Nigeria and service delivery considered to be crucial to the Nigerian citizens in the $21^{\text {st }}$ century.

$\mathbf{H o}^{2}$ There is no significant relationship between leadership styles and strategies (autocratic, laissez-faire, democratic, transactional and transformational) and service delivery (economic wellbeing) of the Nigerian citizens in the $21^{\text {st }}$ century. 


\section{Literature Review}

\section{Concept of Leadership}

Many times, in our everyday speech, the terms leadership and management are often erroneously used interchangeably. It must be noted that the two concepts however are closely related as one must be able to manage in order to lead (Gwavuya, 2011). While management is concerned with the planning, controlling and development of an organisation's resources, leadership is about the alignment of people to the vision of an organisation (Wakabi, 2016). The concept of leadership has evolved over the years from the 1940s to the contemporary time. According to Bass \& Bass (2008), in the 1940s, leadership was seen as the ability to persuade and direct as a result of the influence of power and position but in the present time, leadership is seen as one who is most responsible and accountable for the actions of an organisation.

\section{Leadership Style}

According to Armstrong (2012), a leadership style is the approach used by managers to exercise their leadership function. It is said to be a particular behaviour applied by a leader to motivate his or her subordinates to achieve the objectives of the organization ( $\mathrm{Ng}$ 'ethe, et al. 2012). Leadership style plays an important role in the organisations of today. Leadership style is the way and manner in which a manager or supervisor chooses to act towards his employees or subordinates and the way the leadership function is being carried out by them (Mullins, 2000).

\section{Leadership and Service Delivery in Nigeria}

Leadership, by its nature, involves the exercise of social power. Thus, by exerting a profound effect on personal behaviour, individual and organization productivity, adjustment to working situations, and morale in organizations, leadership should not be viewed separately from social power. Thus, leadership is the ability to influence the behaviour of others in a group or organization, set goals, for the group, formulate paths to the goal and create some social norms in the group (Uveges, 2003) in (Nwagboso, \& Otu, 2012). In every society such as Nigeria, the followers always look on to their leaders to provide certain services to them. Hence, there is a correlation between leadership and service delivery. The primary responsibility of the leader is to deliver services considered to be crucial to the citizenry. In Nigeria, the ability of the government to legitimately tax and govern people is premised on its capacity to deliver a wide range of services required by its population which no other player will provide (Adamolekun, 2002) in (Nwagboso, \& Otu, 2012). Leadership styles and strategies should mobilize and provide quality improvement of goods and services. Leadership should influence effectiveness of service delivery processes to citizens. Leaders through service delivery should influence citizens service attitude and behaviours as well as the interrelationship between these constructs and managerial service delivery inputs.

Thus, poor leadership is, therefore, responsible for poor service delivery to Nigerians. In Nigeria, we must begin to judge the success and failure of our leaders from their ability and vision in delivering their campaign promises to the people. The current crop of leaders in 
Nigeria are only interested in their pockets. Hence, they seem to have redefined what constitutes leadership. Leadership must not only be selfless but also must be able to utilize judiciously the resources of the state in providing people-oriented and quality services to the people. By this, leadership must be viewed as service to the people. It is, therefore, imperative to state that noncompliance to the Constitution of the Federal Republic of Nigeria is the first step in judging our leaders. A visionary leader who desires to deliver quality services to the people must be willing to abide with the Constitution he sworn to obey. This is sacrosanct because, it is from the said Constitution that he derived his powers. In judging the success and failure of former late President Yar'Adua Umaru's administration for instance, Nigerians must first ask the antecedence that made him not to transmit a letter to the National Assembly before proceeding on medical vacation to Saudi Arabia. Some Nigerians have argued that he actually wrote the letter but some members of his cabal - kitchen cabinet, frustrated the letter from getting to the legislature. This singular act explains largely why most democrats in Nigeria have continued to question his sincerity in the over-dramatized excellent leadership qualities. The gravity of this impeachable offence according to Agina (2010) in (Nwagboso, \& Otu, 2012), coerced the Save Nigeria Group (SNG) to conclude: The President's behaviour in the past 67 days by leaving the nation without a leader that has the ability to lead Nigeria proactively has made it obvious that the promises he made to Nigerians on the day of his swearing-in were empty rhetoric. He and his kitchen cabinet have deliberately contrived a situation where a lacuna in leadership at federal level has caused Nigeria to hop from one avoidable crisis to other. The insincerity of our leaders in piloting the affairs of Nigeria for the betterment of all, always manifest on critical national questions or issues.

Well-meaning Nigerians were not comfortable with the late President's action, but some corrupt leaders that were charged to court by the EFCC and ICPC supported the position of the late President for not transmitting power as stipulated by section 145 of the 1999 Constitution to former Vice President Goodluck Jonathan. However, the death of President Yar'Adua brought sadness and pain to Nigerians and the swift take-over by President Goodluck Jonathan gave hope and consolation to the entire nation. Precisely, Ogbuenyi (2010) in (Nwagboso \& Otu, 2012) opine that former Governor of Abia State, Dr. Orji Uzo kalu was among those who supported Yar'Adua "s action. According to Kalu in (Nwagboso, \& Otu, 2012) ....as far as I am concerned, you cannot force a president who has done no wrong to quit until he dies... unless he resigns, there is nothing you can do... and if I were Yar'Adua, to be honest with you, I will not resign... he challenged the National Assembly members to impeach Yar'Adua if they could undergo the due process involved.

\section{Good Leadership as an Indispensable Tool for Goal Attainment in Organization}

The failure of imported western models of leadership to solve the socio-economic and socio-political problems of developing countries like Nigeria is increasingly raising questions in the minds of concerned individuals and organizations all over the world about the efficacy and relevance of these models (Muhammad (2005) in (Nwagboso, \& Otu, 2012). The above position by Muhammad underscores the imperative for good leadership in every human organization. Thus, leadership remains the cornerstone for the accomplishment of desired 
goals in every human organization. Such leadership must not only be people-oriented, but also, the leader(s) must administer the affairs of the organization implicit in the history, cultures, norms, values, yearnings and aspirations of the organization. Why most organizations or countries fail in the attainment of predetermined goals is sometimes traceable to the adherence and application of models of leadership alien to the environment in which leaders operate. Thus, available evidence has shown that no organization or country can grow bigger than the vision of its leadership. This implies that leadership is very important in development-oriented organization (Dogo, 2005) in (Nwagboso, \& Otu, 2012). In Nigeria, several leadership styles have been experimented such as parliamentary, military dictatorship, democratic system, rotational system, among others. The euro-centric models of leadership seem not to have provided desired answers to leadership problems confronting Nigeria. Mohammed (2005) in (Nwagboso, \& Otu, 2012) stated that people have begun to ask; are those systems being practised suitable for our societies? Are they inherently good or bad? Are they being applied cognizant of environmental differences between our society and the societies from which these ideas originated? Do they accommodate our cultural and ideological diversities? How can these western models be modified to suit our environments? How can we solve the leadership problem of our societies? Consequently, the above questions are capable of providing a framework for the administration of the affairs of Nigeria by our leaders if rightly answered. The Nigerian state has passed through various stages of development, yet, the country has not recorded desired achievements. It could, therefore, be concluded that failure of Nigeria in the attainment of desired height could be traceable to the questions posed by Muhammad. Hence, all have not been well with Nigeria in her almost 60 years of nation building.

\section{Interrogating Presidential Leadership Styles and Strategies in Nigeria from 1999 to 2020}

Nigeria has had leaders since after independence that came either through military coup and democratic election. However, for the purpose of this study, we are going to consider the leadership styles and strategies adopted from 1999 to 2020. In the same vein, a president's organizational capacity may be enhanced by his approach and aptitude for working with people; his capacity for managing the multifarious array of stakeholders and political interests is a function of his natural and adaptive style. A president's leadership style also determines whether he will succeed with his team, his cabinet and with legislative and judiciary leaders. A president's style brings with it its strengths and weaknesses to the task of governance. To assess a president's style, we must assess his leadership style and what Greenstein of Princeton University has identified as the qualities that shape presidential performance (Greenstein, 2005).

In the assessments that follow, a key consideration is given to the contextual nature of environment in which these leaders were called to lead. It is easily evident that a president who is well suited to serve in one setting may be ill-suited for another. This is also the justification for a more holistic leadership paradigm that prepares public leaders for effective and result-oriented governance in spite of the environmental conditions and factors. The leadership styles and strategies adopted from 1999-2020 are as follows: 


\section{Direct Leadership Style: President Olusegun Obasanjo}

The direct leadership style produces quick results, moves quickly, makes faster decisions and tends to take charge no matter the circumstance. Generally, in Africa, when we say a leader is strong, we mean he is a direct leader. It may be that since direct leaders thrive in situations where there is crisis, critical deadlines and where people need to do as they are told, this comes across as the natural choice of approach of leadership. However, this style, which is naturally weak in emotional intelligence and careful objective analysis, is prone to excesses if not balanced by other styles. In 1999 General Olusegun Obansanjo decided to run for presidency under the auspices of the People's Democratic Party in the general elections. Obasanjo won with $62.6 \%$ of the votes, sweeping the strongly southeast and the north. Over the next 8 years (1999-2007), President Obansanjo would push for far-reaching socio-economic and political reforms of a size and scope never experienced in the country's history. Again, his direct leadership style brought the needed decisiveness and take-charge approach that a nation battered by years of military dictatorships badly needed.

However, his direct leadership style also began to disenfranchise many of the political actors in his political party and those within his cabinet, as he increasingly came across as autocratic, dictatorial and unyielding on many issues. The most infamous of the issues was the proposed third term bid to keep him in power for another 4 years longer than the constitutionally-prescribed two terms of four years. As the bid progressed many of his allies, his lack of sensitivity to the feelings, needs and perspectives of others increasingly polarized friends and colleagues, leading to massive opposition that ended the third term bid. This ultimately climaxed in political crisis within the ruling party, the People's Democratic Party, which left many sore political and social wounds. A survey of perceptions of presidential leadership style conducted amongst 150 public leaders on senior public leadership programme shows the following perceptions about President Obasanjo (Aduloju, 2011):

- $100 \%$ of respondents believed his leadership style was direct.

- $100 \%$ of respondents believed that his leadership style matched the crisis the country was in when he assumed national leadership the first and second times.

- $100 \%$ of respondents believed that his leadership was insensitive to the feelings of others.

- $\quad 98 \%$ of respondents believed that his leadership left very little space for gaining group harmony and synergy.

- $70 \%$ of respondents believed he had a clear policy vision.

- $52 \%$ of respondents believed he had communication capacity.

- $90 \%$ of respondents believed he did not have emotional intelligence.

We may attribute some of President Obansanjo's leadership styles to nurturing. As a young man that went into the Nigerian Army at 21, there is no much doubt that military training shaped his approach to leadership, which for most military men is a command and control, 
take-charge type of leadership that is typical of the direct leadership style. So, could we say that President Obansanjo is a direct leader by nature or nurture? Is this his default style by nature or nurture? This is not apparently clear. What is however absolutely certain is that his predominant leadership style is direct. The impact of his leadership approach on the culture of governance was as follows:

- Once government was committed to a course of action it was implemented no matter what anyone felt about it.

- Presidential advisors and cabinet members knew that the President could at a moment's notice override their decisions and move in the direction that he desired.

- Political opposition felt that his practices were autocratic and undemocratic.

- Nigeria made significant progress in the liberalization, commercialization and privatization of many critical sectors of the economy.

- Nigeria achieved significant debt profile reduction through a focused economic and federal fiscal administrative agenda.

- Nigeria's real sectors were jump-started and a significant flow of foreign direct investment started to come into the country. This was predominantly due to the decisive nature of the Obasanjo government.

As a direct result of this governance culture, global performance indicators like the Global Competitiveness Index and Doing Business in Nigeria Index improved slightly. However, his much-publicized anti-corruption campaign and economic programmes did not yield long-term dividends as the approaches and methods came to be viewed as an extension of his selective, aggressive, autocratic domineering and overbearing leadership. The end result was by the time President Obasanjo had exited office many issues of state were still in a state of crisis, needing urgent and immediate response.

President Obasanjo's administration would always be remembered for its result-oriented, fast, decisive, aggressive and confrontational approach in getting things done. His government executives have been criticised as being responsible for evolving a governance culture that was insensitive to the feelings of people, domineering, somewhat autocratic and destructive to government bureaucracies.

\section{Systematic Leadership: President Umaru Musa Yar'Adua}

One of the strengths of the systematic leadership style is the capacity to lead through careful planning, objective analysis and fact-based decision making. These qualities enable the systematic leader to be a natural idealist. Idealists tend to be abstract in speech and cooperative in pursuing their goals. Their greatest strength is diplomatic integration of ideas. They usually invest great amounts of their leadership time in ensuring that the basis of their decisions is evidence-based, objective and supported by sound reason. One of the challenges of the systematic leadership style is the ability to act in the midst of ambiguity, conflicting voices and with insufficient information, which is a situation leader in today's world must 
deal with. The late President Umaru Musa Yar'Adua was a systematic leader. He was the President of Nigeria and the 13th Head of State. Before becoming President, he served as governor of Katsina State in northern Nigeria, was declared the winner of the controversial Nigerian presidential election held on 21 April 2007, and was sworn in on 29 May 2007.

True to the systematic style of leadership, Yar'Adua developed what he called his Seven (7) Point Agenda, which was some carefully laid out plans to address seven of Nigeria's most pressing needs, due to the crisis in power, escalation in armed militancy in the Niger Delta and an array of other matters demanding immediate attention. The president's systematic style approach to decision-making was viewed by many critiques as slow, uncommitted and indecisive, failing to respond at an adequate pace to many national challenges and issues. However, in spite of all the criticisms of the Umaru Yar'Adua administration, he is viewed as the primary architect for the development of the world-renowned and highly successful Niger Delta Amnesty Programme.

In this one area more than any other, his systematic leadership style guaranteed that the Federal Republic of Nigeria developed a long-term strategy for eliminating armed militancy in the Niger Delta region, which right up to 2007 was the main international security threat in the Gulf of Guinea, a region that accounted for the sixth largest export of crude oil globally. When President Yar'Adua assumed office in 2007, the world was in a global financial crisis.

The economic performance of Nigeria prior to the crisis in 2007 was below official projection, with an estimated GDP growth of $6.2 \%$, set against a growth target of $10 \%$, indicating a slight growth from the $6.0 \%$ recorded in 2006 which was driven primarily by the non-oil sector, which grew by $9.6 \%$. Largely attributable to the agriculture sector, this grew by $7.4 \%$, led by crop production, livestock and fishing. Other key components of growth in non-oil GDP consisted of wholesale and retail trade, building and construction and services, which recorded growth rates of $15.3 \%, 13.0 \%$ and $9.8 \%$ respectively. Industrial output dropped by $3.5 \%$, due to the $5.9 \%$ drop in crude oil production as a result of the Niger Delta crisis.

At the close of the fiscal year 2007, the national crude oil production closed at a shocking 0.9 million barrels a day. Nigerian National Petroleum Company (NNPC) reports showed that the Federal Republic of Nigeria lost N16.9 billion to petroleum pipeline vandalism and militant attacks on other petroleum sector-critical infrastructure. As a result, the downstream sector of the petroleum industry was functionally inactive, and the nation relied on imported refined petroleum products for domestic and industrial operations. The Federal Republic of Nigeria consumed about 14.13 billion litres of refined petroleum products (38.7 million litres per day) in 2007, with Premium Motor Spirit (PMS) accounting for 9.81 billion litres. At the close of the third quarter of 2007, the Manufacturers' Association of Nigeria (MAN) reported a drop in manufacturing capacity utilization from $44.06 \%$ in 2006 to $43.5 \%$, owing to the difficult operating environment. The industrial sector made a negative contribution of 0.78 percentage points.

President Yar'Adua's administration developed an integrated strategy for dealing with the militancy challenge. He consulted with regional leaders rigorously over a one-year period, carefully studying the challenges of the region. He was the first leader in Nigerian history to 
agree that the injustices committed against the minorities in the oil-rich Niger Delta, which resulted in environmental degradation and impoverishment of the ethnic groups in the region, had to be corrected. His strategy included: The review of the Niger Delta Development Master Plan, which gave President Umaru Yar'Adua the basis for negotiating an amnesty deal with leaders of the militant groups. The development of a phased Amnesty Programme which consisted of:

- Militant Disarmament and De-militarization

- Ex-Militant Reorientation

- The creation of the Federal Ministry of Niger Delta Affairs, a dedicated government institution that was focused on eliminating years of neglect in the development of socio-economic well-being of the people of the region, headed by a cabinet level minister, who was mandated to implement the Niger Delta Development Master Plan;

- A well-orchestrated military strategy to de-militarize the Niger Delta region through joint security forces to clean up campaigns targeted at militant camps;

- A coordinated intelligence strategy for isolating militant groups that would not come to the negotiating table with the Federal Government.

Though the development of the strategy took a long time (one year in the minds of many of his critics was too long to wait), it worked. Tens of thousands of youth militants voluntarily disarmed throughout 2008 and 2009, relative peace returned to the region, and international oil companies resumed oil production.

\section{The Systematic Leader Wins}

As a result of the full implementation of this strategy, Africa witnessed one of the largest and most successful disarmament and de-militarization programmes on the continent, and Nigeria experienced an increase in oil production. Oil production made a substantial recovery post-Niger Delta Amnesty in the Yar'Adua administration. Oil prices stabilized averaging US\$77.65/ per barrel in the first half of 2010 versus the benchmark price of US\$60/per barrel. Oil GDP growth was up 4.4\% year to date versus $0.0 \%$ growth in the same period in 2009 . President Yar'Adua died on the 5th of May 2010, after a protracted illness. Yar'Adua systematic leadership style created a slow-paced presidential decision-making process, which resulted in a governance culture where too many matters were pending presidential attention. His tendency to focus on details and objective analysis as a person reduced the number of things he could achieve. Ultimately his Seven Point Agenda was criticised because his pace of decision meant he could not focus on Seven Points. Many critics recommended he focused on only one point.

A survey of perceptions of presidential leadership style conducted amongst 150 public leaders shows the following perceptions about President Yar'Adua (Aduloju, 2011):

- $100 \%$ of respondents believed his leadership style was systematic. 


\section{Macrothink}

Journal of Public Administration and Governance ISSN 2161-7104 2021, Vol. 11, No. 2

- $10 \%$ of respondents believed that his leadership did not style matched the crisis the country was in when he assumed national leadership (in other words $90 \%$ felt his systematic style did not match the crisis).

- $60 \%$ of respondents believed that his leadership was insensitive to the feelings of others.

- $90 \%$ of respondents believed that his leadership was effective at gaining group harmony and synergy.

- $80 \%$ of respondents believed he had a clear policy vision.

- $20 \%$ of respondents believed he had communication capacity.

- $75 \%$ of respondents believed he did not have emotional intelligence.

\section{President Goodluck Jonathan: The Considerate Leader}

President Goodluck Jonathan was known for his propensity for looking for more consensus than necessary. He was known to consult widely with others before making decisions. On his assumption of office, he sought to inspire national leaders to work together, which was a welcome approach to leadership in Nigeria. However, his continuous consultative style soon attracted bitter rebukes from all quarters, as the Book Haram terrorism threat, a new national security challenge, emerged in the northern region of Nigeria, which citizens felt required quick, aggressive and decisive action. Many commentators were worried that the President's lack of decisiveness on a clear national security strategy and response gave the terrorists opportunities for incursion across the country, resulting in a devastating trend that again brought Nigeria back into global focus as a nation where terrorism had taken root. His tendency to be too patient with government executives that were perceived to be underperforming was another key weakness of his administration.

Furthermore, the tendency of President Jonathan's administration to have myriad consultative committees and taskforces, which seek to harmonize and synergize amongst an array of national stakeholders, was ultimately now viewed as a weakness of his administration to act quickly, move decisively and respond adequately to new and emerging national challenges. In the last year of his administration, GEJ called the national conference to create the platform for some of the most robust discussions on the Nigerian state in recent times and to gain consensus on the way forward for the Federal Republic of Nigeria.

In the final analysis, it was his considerate leadership style that prevailed in his early concession of electoral defeat to President Buhari, an act that might have saved Nigeria from the brink of chaos and political violence.

\section{General Muhammadu Buhari: The Systematic Leader}

The survey of perceptions of presidential leadership style conducted amongst 150 public leaders shows the following perceptions about General Buhari, when he was head of state (Aduloju, 2011): 
- $\quad 98 \%$ of respondents believed his leadership style was systematic.

- $90 \%$ of respondents believed that his leadership style matched the country at that time as a military dictator

- $82 \%$ of respondents believed that his leadership was insensitive to the feelings of others.

- $30 \%$ of respondents believed that his leadership was effective at gaining group harmony and synergy.

- $92 \%$ of respondents believed he had a clear policy vision.

- $23 \%$ of respondents believed he had communication capacity.

- $85 \%$ of respondents believed he did not have emotional intelligence.

It is clear that the then President Buhari was predominantly a systematic, though as a military dictator, the posture of his administration was direct, partly due to the influence of key figures in his government.

\section{The Second Coming of GMB and the New Imperatives of Presidential Leadership Maturity}

Now, GMB is back as President Muhammadu Buhari (PMB), and already we can see him resort to his default presidential leadership style, beginning with the setting up of Transitional Team of the APC, who submitted their report on 12th of June 2015. Already the systematic president is being called "Baba Go Slow", due to his insistence on subjecting everything to objective analysis and his demand for fact-based recommendations on all matters, to the careful and meticulous process he is taking in personally assessing the prospects for cabinet and his advisory pool. Our systematic president is showing his unwillingness to engage in matters of ambiguity evidenced from his posture on the National Assembly leadership evolution process and his reluctance to simply comment on everything without having all the facts. Some have argued that he is not talking enough about major APC party issues, he is allowing too much to chance, he is too slow, and has refused to hit the ground running. The allegations and criticisms are endless. Our classical systematic president is living up to this style!

There are benefits to PMB's approach at the beginning of his administration. For the Change Agenda to be translated to tangible outcomes citizens' demand:

- He carefully assesses the government and nation he has received. No amount of outsider information prepares you for what you meet in office on day one;

- He objectively and proactively selects a federal cabinet and Presidential Advisory Team from our country's best and brightest to work with him to translate his vision of change into reality;

- He leads Nigeria through the articulation of a robust National Change Policy, Strategy and Master Plan; 
The country demands nothing less, than a systematic approach to settling government down to tackle our most formidable problems. But like PMB has done on matters of national security, our country has many issues that require a greater sense of urgency, an acute sensitivity to the feelings and aspirations of the Nigerian people and a more robust execution framework. This will depend on the accelerated constitution and deployment of his presidential team. Finally, we demand that our beloved PMB transforms himself! He must rise above his default leadership style and become a full stature presidential leader that must:

- Display Considerate Approaches (by rallying, aligning and synergizing consensus for determinate, decisive and impactful action within and outside the APC and across all the geopolitical zones, ethnic and religious lines);

- Display Spirited Approaches (by inspiring Nigerians with words of faith, confidence, affirmation and action to belief that we can and we will see under his leadership the emergence of a peaceful, powerful, prosperous and great nation);

- Display Direct Approaches (by taking charge of the APC Agenda, decisively dealing with distractions, clearly obstacles out of the way, fighting corruption head on and providing strong leadership and aggressive action towards reinventing governance and changing the fortunes of the Nigerian people).

It is our belief that the PMB that Nigerians voted into office is more than capable of full stature presidential leadership - This is the new national leadership Imperative and it will significantly determine the culture of governance going forward.

\section{Factors That Determine Leadership Style}

There are a number of factors that can help to determine which type of leadership style is most effective and/or when to draw on a different or combination of leadership styles. Listed below are a number of these factors as outlined by Ibara (2010):

\section{Size of an Institution/Organization}

Many organizations have the tendency to grow, and as they grow, to divide into subgroups where the real decision-making power lies. As institutions or organization grow, problems arise which may become more difficult to address at a macro or senior management level. At the same time, as institutions and organizations grow larger and become more multifaceted, there is a propensity for decision making to be centralized (Naylor, 1999). This situation leads to limited employee participation or no participation at all. Leaders may, if inclined, present ideas and invite input from employees (Ibara, 2010).

\section{Degree of Interaction/Communication}

Organizational interaction or communication in this paradigm refers to a relational approach between two or more individuals on the basis of social and organizational structures aimed at achieving goals (Ololube, 2012). Given that uncertainty surrounds many situations in organizations, leaders need to be involved with their staff. In this way, leaders can keep focused on key issues and ensure that organizational learning takes place. 


\section{Leadership Styles}

Leadership styles are the approaches used to motivate followers. Leadership is not a "one size fits all" phenomenon. Leadership styles should be selected and adapted to fit organizations, situations, groups, and individuals. Below are a number of leadership styles articulated in the Toolkit (n.d):

\section{Autocratic Leadership Style}

Autocratic leaders, who are also known as authoritarian leaders, provide clear explanations for what the task is, what exactly has to be done, when the deadlines are and the way it should be done in. This leadership style is instructions-centric and the ways of controlling the followers. There is also a clear distinction between the leader and the followers. Autocratic leaders make decisions independently with very few or even sometimes no input is done by the rest of the group. Researchers found that decision-making blocked creativity and put limits in the faces of followers under the autocratic leadership. Lew in also found that it is more difficult to move from the autocratic leadership style to a democratic style than from a democratic leadership style to the authoritarian one. The negative part of this style is that it is usually viewed as controlling, bossy, and dictatorial (Lewin, Lippit, \& White, 1939). Autocratic leaders are very powerful and do usually show clear distinction between them and their subordinates. They adopt order in dealing with their staff.

\section{Bureaucratic Leadership Style}

Bureaucratic leaders follow rules rigorously, and ensure that their staff also follow procedures precisely. This is an appropriate leadership style for work involving serious safety risks (such as working with machinery, with toxic substances, or at dangerous heights) or where large sums of money are involved. Bureaucratic leadership is also useful in organizations where employees do routine tasks (Shaefer, 2005). Everything is done following laydown rules, systems, processes and procedures at workplace. they insist on doing the right thing by following the right procedure. The drawback of this type of leadership is that it is ineffective in teams and organizations that rely on flexibility, creativity, or innovation (Santrock, 2007).

\section{Charismatic Leadership Style}

Charismatic leadership theory describes what to expect from both leaders and followers. Charismatic leadership is a leadership style that is identifiable but may be perceived with less tangibility than other leadership styles (Bell, 2013). Charismatic leaders do carry their followers along. They usually have a voice that motivates followers to keep following. Their relationship with followers often encourages their followers to positively work to the attainment of set goals. Often called a transformational leadership style, charismatic leaders inspire eagerness in their teams and are energetic in motivating employees to move forward.

\section{Democratic/Participative Leadership Style}

Democratic leaders usually involve subordinate in the process of decision making even though, make the final decisions, but include team members in the decision-making process given staff the sense of belonging. They encourage creativity and innovation thereby 
encouraging team members to be highly engaged in projects and decision making in an organization. There are many benefits of democratic leadership. Team members tend to have high job satisfaction and are productive because they are more involved. This style also helps develop employees' skills. Anderson, (1959) identified the democratic leader as one who shares decision making with the other members and therefore, democratic leadership is connected with higher morale in the majority of the situations. Hackman and Johnson, (1996) supported Andersons explanation of the relationship between democratic leadership and productivity.

\section{Laissez-Faire Leadership Style}

Laissez-faire leadership may be the best or the worst of leadership styles (Goodnight, 2011). Laissez-faire, this French phrase for "let it be," when applied to leadership describes leaders who allow people to work on their own. They usually adopt a care free attitude to issues and allow things to happen anyhow. Laissez-faire leaders abdicate responsibilities and avoid making decisions, they may give teams complete freedom to do their work and set their own deadlines. Laissez-faire leaders usually allow their subordinate the power to make decisions about their work (Chaudhry \& Javed, 2012).

\section{Transactional Leadership Style}

This leadership style starts with the idea that team members agree to obey their leader when they accept a job. The transaction usually involves the organization paying team members in return for their effort and compliance. It eases supervision during division of labour in and organization based on the loyalty of team leaders to leaders. Transactional leadership, also known as management theories, focus on the role of supervision, organization and group performance and the exchanges that take place between leaders and followers. These theories base leadership on a system of rewards and punishments (Charry, 2012). In other words, on the notion that a leader's job is to create structures that make it abundantly clear what is expected of followers and the consequences (rewards and punishments) associated with meeting or not meeting expectations (Lamb, 2013). When employees are successful, they are rewarded and when they fail, they are reprimanded or punished (Charry, 2012). Managerial or transactional theory is often likened to the concept and practice of management and continues to be an extremely common component of many leadership models and organizational structures (Lamb, 2013).

\section{Theories of Leadership}

This study is anchored by certain theories as a justification to the study considering facts of other scholars about leadership styles and strategies. Although new theories are emerging all of the time, most can be classified as one of Charry's eight major types:

\section{Great Man Theory}

Great man theories assume that the capacity for leadership is inherent, that great leaders are born, not made. These theories often portray leaders as heroic, mythic and destined to rise to leadership when needed. The term great man was used because, at the time, leadership was 
thought of primarily as a male quality, especially military leadership (Ololube, 2013).

\section{Trait Theory}

Similar in some ways to great man theories, the trait theory assumes that people inherit certain qualities or traits make them better suited to leadership. Trait theories often identify particular personality or behavioural characteristics that are shared by leaders. Many have begun to ask of this theory, however, if particular traits are key features of leaders and leadership, how do we explain people who possess those qualities but are not leaders? Inconsistencies in the relationship between leadership traits and leadership effectiveness eventually led scholars to shift paradigms in search of new explanations for effective leadership.

\section{Contingency Theories}

Contingency theories of leadership focus on particular variables related to the environment that might determine which style of leadership is best suited for a particular work situation. According to this theory, no single leadership style is appropriate in all situations. Success depends upon a number of variables, including leadership style, qualities of followers and situational features (Charry, 2012). A contingency factor is thus any condition in any relevant environment to be considered when designing an organization or one of its elements (Naylor, 1999). Contingency theory states that effective leadership depends on the degree of fit between a leader's qualities and leadership style and that demanded by a specific situation (Lamb, 2013).

\section{Situational Theory}

Situational theory proposes that leaders choose the best course of action based upon situational conditions or circumstances. Different styles of leadership may be more appropriate for different types of decision-making. For example, in a situation where the leader is expected to be the most knowledgeable and experienced member of a group, an authoritarian style of leadership might be most appropriate. In other instances where group members are skilled experts and expect to be treated as such, a democratic style may be more effective.

\section{Behavioural Theory}

Behavioural theories of leadership are based on the belief that great leaders are made, not born. This leadership theory focuses on the actions of leaders not on intellectual qualities or internal states. According to the behavioural theory, people can learn to become leaders through training and observation. Naylor (1999) notes that interest in the behaviour of leaders has been stimulated by a systematic comparison of autocratic and democratic leadership styles. It has been observed that groups under these types of leadership perform differently:

Autocratically led groups will work well so long as the leader is present. Group members, however, tend to be unhappy with the leadership style and express hostility.

Democratically led groups do nearly as well as the autocratic group. Group members have 
more positive feelings, however, and no hostility. Most importantly, the efforts of group members continue even when the leader is absent.

\section{Theoretical Bases}

For the purpose of the study, the study has adopted Situational Theory, as the theoretical base because, the theory proposes that, leaders choose the best course of action based upon situational conditions or circumstances. This is a reflection of the leadership approaches of Nigerian leaders in the $21^{\text {st }}$ century. President Obasanjo when faced with the challenge of corruption leading Nigeria been declared by the transparency initiative as one of the corrupt nations in the world, he quickly acted to the situation by establishing EFCC and the ICPC to tackle corruption. President Yar'Adua's administration when he noticed that his government inherited the Niger Delta youths' unrest, he granted them amnesty and also empowered them. $\mathrm{He}$ also created a Niger Delta Ministry. President Goodluck Jonathan also exhibited situational approach to leadership when the insecurity in the North East continued to increase and was attributed to the rate of illiteracy in the region, he established the Almajiri schools in the entire northern Nigeria to reduce illiteracy. President Muhammadu Buhari also inherited the Boko Haram insurgence and quickly moved the military formation to the North East under the leadership of General Buratai to tackle it. These were some of the situational decisions made by the Nigerian Leaders to manage some of the leadership challenges faced in the $21^{\text {st }}$ century.

\section{Empirical Review}

Adedamola (2016) investigated the Impact of Leadership Styles on Employee Retention: Identifying which Leadership Style best encourages Employee Retention in the Nigerian Banking Sector using Zenith Bank Plc, Nigeria as a case study. Employee retention is a major concern of the Nigerian banking sector today because of increased employee turnover. The primary data for this study was collected through questionnaires and analysed using the Statistical Package for Social sciences (SPSS). Data was collected through both open ended and close ended questions with a five-point Likert scale. The study revealed that leadership style has a moderate significance on employee retention and that the transactional leadership style best encourages employee retention in the Nigerian Banking sector. The study recommends that leaders and managers should properly implement the exchange process of the transactional leadership style to mitigate employee turnover in the Nigerian banking sector.

Nneoma, et al, (2014) studied: The Influence of "Nigerian Culture" on Leadership and its Implication on the Sustainable Development of the Nation. The need for good leadership has been emphasized as an ingredient necessary for the progress and development of a nation. It has been observed that the development of the nation has been at a very slow pace since independence, many studies attribute this to the poor state of leadership in the Nation. The culture of corruption was extensively examined and it was revealed that the followers contribute greatly to the corrupting influence of the leaders. The culture of interdependency, "godfatherism", nepotism and the effect they have on sustainable development was also examined. The challenges of leadership and governance in Nigeria and the implications of 
this social menace as well as the role of Anti-corruption Agency in the fighting of corruption was critically examined.

Nwagboso \& Duke (2012) in their work investigated: Nigeria and the Challenges of Leadership in the 21st Century: A Critique. This paper attempts a critical exposition of leadership challenge of Nigeria, especially in this $21^{\text {st }}$ century. The paper examines the extent to which inept and corrupt leadership have over the years, adversely affected the development of Nigeria as a nation. The study adopts descriptive approach and content analysis as its methodological orientation. The paper, however, concludes that official corruption which has hitherto cascaded Nigeria's developmental efforts certainly emanated from poor leadership and needs to be addressed if Nigeria must attain greater heights by the year 2020. The paper therefore recommends among others, the need for Nigerians to urgently reflect back on the values, visions and aspirations of Nigeria's founding fathers and the institutionalization of leadership training centres at local government levels across the country as platform for the emergence of credible leaders at local, state and national levels in Nigeria.

\section{Study Gap}

Series of studies have been conducted on the leadership styles in Nigeria in the $21^{\text {st }}$ century using economic development, banking sector, SMEs etc., but failed to examine the relationship that exists between leadership styles and strategies, service delivery to citizens in Nigeria and citizens wellbeing in the $21^{\text {st }}$ century. This study however exists to fill such existing gap.

\section{Research Methodology}

This study adopted survey research design basically because it is simply most suitable for the study. Data were collected mainly through the primary (questionnaire) secondary source of data and these were also complimented with interviews with Nigerians the staff of some selected staff of certain agencies and ministries in Abuja, from 1999-2020. Nigeria. The model adopted for study is theory driven model, the use of simple percentages and correlation analysis to ascertain the relationship between the existing variables in the study using SPSS Package. The sample size was two hundred and thirty-six (236) respondents and data were collected using a 4-point Likert scale with options as Strongly Agree (SA), Agree (A), Strongly Disagree (SD) and Disagree. A pilot test was conducted using the Cronbach's Alpha Computation at $0.7 \%$ to ascertain Reliability and Validity of the instruments used. The questionnaire used for the study and designed into three (3) sections of: A, B and C to gather possible information from the respondents. Section A is to gather data on the respondents' biodata, section B covers the leadership styles and Strategies while section C covers the Impact of the leadership styles on the service delivery to citizens in Nigeria and citizens wellbeing in the $21^{\text {st }}$ century. The population of this study covers all the 43 federal ministries in Nigeria. Purposive sampling method was adopted for the selection of the sample size from the five (5) federal government ministries in Nigeria by choosing 50 staff from each of the companies under study to be adopted as respondents for the study. From the five (5) federal government ministries in Nigeria, 250 staff were randomly served with questionnaires as the sample size as follows: 
Table 1. Respondents' Distribution

\begin{tabular}{|c|l|c|c|c|}
\hline S/No. & \multicolumn{1}{|c|}{ Respondents } & $\begin{array}{l}\text { Questionnaire } \\
\text { Distributed }\end{array}$ & $\begin{array}{l}\text { Questionnaire } \\
\text { Returned }\end{array}$ & $\begin{array}{c}\text { Questionnaire } \\
\text { Not Returned }\end{array}$ \\
\hline 1 & Federal Capital Territory (FCT) & 50 & 47 & 03 \\
\hline 2 & $\begin{array}{l}\text { Federal Ministry of Education } \\
\text { \& Youth Development }\end{array}$ & 50 & 46 & 04 \\
\hline 3 & $\begin{array}{l}\text { Federal Ministry of Works and } \\
\text { Housing Ministry of }\end{array}$ & 50 & 49 & 01 \\
\hline 4 & $\begin{array}{l}\text { Federal Ministry of } \\
\text { Environment }\end{array}$ & 50 & 46 & 04 \\
\hline 5 & $\begin{array}{l}\text { Federal Total } \\
\text { Transportation }\end{array}$ & $\mathbf{2 5 0}$ & $\mathbf{2 3 6}$ & $\mathbf{1 4}$ \\
\hline
\end{tabular}

Source: Field Survey, (2020)

Table 1 reveals a total of 250 copies of questionnaires that were produced, structured and distributed to the respondents from the five (5) federal government ministries, and from the entire questionnaire distributed, 236 copies representing $96 \%$ were completed returned and used for the study while 14 copies representing $4 \%$ were not returned respectively. The study also adopted both descriptive and inferential statistics for data collection, presentation and analysis. Correlation analysis were used to establish the strength of the relationship existing between the independent and the dependent variables with an acceptance conventional significant level of $\mathrm{P}=0.05$. Also, simple linear regression analysis was used to test the hypotheses in the study using SPSS (Version 23) to analyze the results

\section{Estimation of the Study Variables}

For the purpose of this study, the independent variable is the Leadership Styles and Strategies (LSS) measured by (autocratic, laissez-faire, democratic, transactional and transformational). While the dependent variables are Service Delivery (SD) also measured by Economic Wellbeing (EW). The independent and dependent variables are measured using multiple regression model. The model is given as follows:

$\mathrm{Y}=\mathrm{f}\left(\mathrm{X}_{1}\right)$

$\mathrm{Y}=\beta_{0}+\beta_{1} \mathrm{X}_{2}+\mu$

$\mathrm{SD}=\alpha+\beta_{1} \mathrm{LSS}+\varepsilon \mathrm{I}$

Where:

$\mathrm{SD}=$ Service Delivery (dependent variable), $\alpha$ is the intercept, $\beta_{l}$, is the independent variable such as Leadership Styles and Strategies (LSS) measured by (autocratic, laissez-faire, democratic, transactional and transformational) and $\varepsilon \mathrm{I}$ is the error term. This model was developed by the researcher 2020 .

The questionnaire was tested for content validity and reliability to determine the appropriateness of the instruments used which transmits to the questions being answered been 


\section{Macrothink}

Journal of Public Administration and Governance

ISSN 2161-7104

2021, Vol. 11, No. 2

answered in the study. However, Cronbach's alpha is used to measure the internal consistency. According to Sekran, (2001) Alpha values for each instrument under study should not be less than 0.7 . The validity of the data collection instruments was done with help of questionnaires the result of the reliability test is presented in the table below.

Table 3.1. Test for validity and reliability using Cronbach's Alpha

Scale Reliability of Variables

\begin{tabular}{|l|l|}
\hline Items & Cronbach's Alpha \\
\hline $\begin{array}{l}\text { Leadership Styles and } \\
\text { Strategies }\end{array}$ & 0.82 \\
\hline Service Delivery & 0.75 \\
\hline Economic Wellbeing & 0.80 \\
\hline
\end{tabular}

Source: Researchers' Computation (2020)

Table 3.1 shows the test for reliability and validity for Cronbach's Alpha. The independent items consist of Leadership Styles and Strategies (LSS) measured by (autocratic, laissez-faire, democratic, transactional and transformational) and dependent items (Service Delivery and Economic Wellbeing) with Alpha value greater than 0.7 which is adequate for the study according to Sekran 2001.

\section{Data Presentation and Analysis}

\section{Results and Discussion}

The paper adopted correlation and regression analysis statistical tools specified using SPSS (Version 23) to analyze the results as thus:

\section{Hypothesis Testing}

Table: 2

$\mathbf{H}_{\text {O1: }}$ : There is no significant relationship between leadership styles and strategies adopted in Nigeria and service delivery considered to be crucial to the Nigerian citizens in the $21^{\text {st }}$ century. 
Table 2. Coefficients ${ }^{\mathrm{a}}$

\begin{tabular}{|c|c|c|c|c|c|c|}
\hline \multirow{2}{*}{} & \multicolumn{2}{|c|}{$\begin{array}{c}\text { Unstandardized } \\
\text { Coefficients }\end{array}$} & $\begin{array}{c}\text { Standardized } \\
\text { Coefficients }\end{array}$ & \multirow{2}{*}{} & \multirow{2}{*}{ Sig. } \\
\cline { 3 - 5 } \multicolumn{2}{c|}{ Model } & B & Std. Error & Beta & T & Sig. \\
\hline \multirow{2}{*}{1} & (Constant) & .822 & .134 & & 8.422 & .000 \\
\cline { 2 - 7 } & LLS & 5.946 & 1.240 & 0.0632 & 0.884 & 0.387 \\
\hline
\end{tabular}

a. Dependent Variable: Service Deliver to Citizens

Source: Field Survey, (2020)

The regression results of Leadership Styles and Strategies (LSS) indicates that there is a positive relationship existing between the two variables leadership styles and strategies and service delivery of citizens in Nigeria but not significant in achieving service delivery in terms of the wellbeing of citizens with the standard error of 1.240, and a P-value of 0.387 which is greater than $0.05(5 \%)$ level of significance. The study accepts the null hypothesis that states that, there is no significant relationship between leadership styles and Strategies adopted in Nigeria and service delivery considered to be crucial to the Nigerian citizens in the $21^{\text {st }}$ century.

Table 3. Pearson Correlation Analysis

\begin{tabular}{|l|l|c|c|}
\hline & & $\begin{array}{l}\text { Leadership Styles } \\
\text { and Strategies }\end{array}$ & $\begin{array}{l}\text { Service Delivery to } \\
\text { Citizens }\end{array}$ \\
\hline $\begin{array}{l}\text { Leadership Styles } \\
\text { and Strategies }\end{array}$ & $\begin{array}{l}\text { Pearson Correlation } \\
\text { Sig (2-tailed) }\end{array}$ & 1 & $533^{* *}$ \\
$\mathrm{~N}$ & 236 & 0.0000 \\
\hline Service Delivery to & Pearson Correlation & $.533^{* *}$ & 236 \\
Citizens & Sig (2-tailed) & 0.0000 & 1 \\
& $\mathrm{~N}$ & 236 & 236 \\
\hline
\end{tabular}

*Correlation is significant at the 0.05 level (SPSS, Version 23)

Source: Field Survey, (2020)

Table 3 shows that, the calculated correlation coefficient figures of $r=0.533$ at 0.05 significant level. Since the calculated value is greater than the tabulated $r$ value, then the null hypothesis that stated that, there is no significant relationship between leadership styles and Strategies adopted in Nigeria and service delivery considered to be crucial to the Nigerian citizens in the $21^{\text {st }}$ century is hereby rejected and the alternative hypothesis that, there is a significant relationship between leadership styles and strategies adopted in Nigeria and service delivery considered to be crucial to the Nigerian citizens in the $21^{\text {st }}$ century. 


\section{Macrothink}

Table: 4

$\mathbf{H o}^{2}$ : There is no significant relationship between leadership styles and strategies (autocratic, laissez-faire, democratic, transactional and transformational) and economic wellbeing of the Nigerian citizens in the $21^{\text {st }}$ century.

Table 4. Co-efficients ${ }^{\mathrm{a}}$

\begin{tabular}{|c|c|c|c|c|c|c|}
\hline \multirow{2}{*}{\multicolumn{2}{|c|}{ Model }} & \multicolumn{2}{|c|}{$\begin{array}{c}\text { Unstandardized } \\
\text { Coefficients }\end{array}$} & \multirow{2}{*}{$\begin{array}{c}\begin{array}{c}\text { Standardized } \\
\text { Coefficients }\end{array} \\
\text { Beta }\end{array}$} & \multirow[b]{2}{*}{$\mathrm{T}$} & \multirow[b]{2}{*}{ Sig. } \\
\hline & & B & Std. Error & & & \\
\hline \multirow[t]{2}{*}{1} & (Constant) & .723 & .142 & & 5.646 & .000 \\
\hline & LLS & 3.232 & 2.312 & 0.039 & 0.422 & .673 \\
\hline
\end{tabular}

a. Dependent Variable: Economic Wellbeing

Source: Field Survey, (2020)

The regression results of leadership styles and strategies (LSS) indicates that there is a positive relationship existing between the two variables leadership styles and strategies and the economic wellbeing of citizens in Nigeria but not significant in achieving wellbeing of citizens with the Std. Error of 2.312, and a P-value of 0.673 which is greater than $0.05(5 \%)$ level of significance. The study accepts the null hypothesis that states that, there is no significant relationship between leadership styles and strategies (autocratic, Laissez-faire, democratic, transactional and transformational) and economic wellbeing of the Nigerian citizens in the $21^{\text {st }}$ century.

Table 5. Pearson Correlation Analysis

\begin{tabular}{|l|l|c|c|}
\hline & & $\begin{array}{l}\text { Leadership Styles } \\
\text { and Strategies }\end{array}$ & Economic Wellbeing \\
\hline $\begin{array}{l}\text { Leadership Styles } \\
\text { and Strategies }\end{array}$ & Pearson Correlation & 1 & $511^{* *}$ \\
& Sig (2-tailed) & N & 0.000 \\
\hline Economic Wellbeing & Pearson Correlation & $0.511^{* *}$ & 236 \\
& Sig (2-tailed) & 0.000 & 1 \\
& $\mathrm{~N}$ & 236 & 236 \\
\hline
\end{tabular}

*Correlation is significant at the 0.05 level (SPSS, Version 23)

Source: Field Survey, (2020)

Table 5 reveals that, the calculated correlation coefficient figures of $r=0.511$ at 0.05 significant level. Since the calculated value is greater than the tabulated $r$ value, then the null hypothesis that stated that, there is no significant relationship between leadership styles and strategies (autocratic, laissez-faire, democratic, transactional and transformational) can influence the wellbeing of the Nigerian citizens in the $21^{\text {st }}$ century is hereby rejected and the 
alternative hypothesis that, there is a significant relationship between leadership styles and strategies (autocratic, laissez-faire, democratic, transactional and transformational) and economic wellbeing of the Nigerian citizens in the $21^{\text {st }}$ century.

\section{Discussion of Major Findings}

The analysis in hypothesis 1: The findings were that, the regression results of leadership styles and strategies (LSS) indicates that there is a positive relationship existing between the two variables leadership styles and strategies and service delivery of citizens in Nigeria but not significant in achieving service delivery in terms of the wellbeing of citizens with the standard error of 1.240, and a P-value of 0.387 which is greater than $0.05(5 \%)$ level of significance. The study accepts the null hypothesis that states that, there is no significant relationship between leadership styles and strategies adopted in Nigeria and service delivery considered to be crucial to the Nigerian citizens in the $21^{\text {st }}$ century. This is in corroboration with the calculated correlation coefficient figures of $r=0.533$ at 0.05 significant level. Since the calculated value is greater than the tabulated $r$ value, then the null hypothesis that stated that, there is no significant relationship between leadership styles and strategies adopted in Nigeria and service delivery considered to be crucial to the Nigerian citizens in the $21^{\text {st }}$ century is hereby rejected and the alternative hypothesis that, there is a significant relationship between leadership styles and strategies adopted in Nigeria and service delivery considered to be crucial to the Nigerian citizens in the $21^{\text {st }}$ century. This study is in agreement with the study conducted by Nwagboso \& Duke (2012) on Nigeria and the Challenges of Leadership in the 21st Century: A Critique. This paper attempts a critical exposition of leadership challenge of Nigeria, especially in this $21^{\text {st }}$ century. The paper examines the extent to which inept and corrupt leadership have over the years, adversely affected the development of Nigeria as a nation. The study adopts descriptive approach and content analysis as its methodological orientation. The paper, however, concludes that official corruption which has hitherto cascaded Nigeria's developmental efforts certainly emanated from poor leadership and needs to be addressed if Nigeria must attain greater heights by the year 2020. Also, the study agrees with the work of Nneoma, et al, (2014) on: The Influence of "Nigerian Culture" on Leadership and its Implication on the Sustainable Development of the Nation. The need for good leadership has been emphasized as an ingredient necessary for the progress and development of a nation. It has been observed that the development of the nation has been at a very slow pace since independence, many studies attribute this to the poor state of leadership in the Nation. The culture of corruption was extensively examined and it was revealed that the followers contribute greatly to the corrupting influence of the leaders.

The Analysis in hypothesis 2, the findings were that, the regression results of Leadership Styles and Strategies (LSS) indicates that there is a positive relationship existing between the two variables leadership styles and strategies and the economic wellbeing of citizens in Nigeria but not significant in achieving wellbeing of citizens with the standard error of 2.312, and a P-value of 0.673 which is greater than $0.05(5 \%)$ level of significance. The study accepts the null hypothesis that states that, there is no significant relationship between leadership styles and strategies (autocratic, laissez-faire, democratic, transactional and transformational) and wellbeing of the Nigerian citizens in the $21^{\text {st }}$ century. The calculated 
correlation coefficient figures of $r=0.511$ at 0.05 significant level. Since the calculated value is greater than the tabulated $r$ value, then the null hypothesis that stated that, there is no significant relationship between leadership styles and strategies (autocratic, laissez -faire, democratic, transactional and transformational) and economic wellbeing of the Nigerian citizens in the $21^{\text {st }}$ century is hereby rejected and the alternative hypothesis that, there is a significant relationship between leadership styles and strategies (autocratic, laissez -faire, democratic, transactional and transformational) and the Economic wellbeing of the Nigerian citizens in the $21^{\text {st }}$ century. This study is equally in agreement with the study of this study agrees with the work of Adedamola, (2016) on: An Investigation into the Impact of Leadership Styles on Employee Retention: Identifying which Leadership Style best encourages Employee Retention in the Nigerian Banking Sector. A Case study of Zenith Bank Plc, Nigeria. Employee retention is a major concern of the Nigerian banking sector today because of increased employee turnover. Also, the study agrees with the work of Nneoma, et al, (2014) on: The Influence of "Nigerian Culture" on Leadership and its Implication on the Sustainable Development of the Nation. The need for good leadership has been emphasized as an ingredient necessary for the progress and development of a nation. It has been observed that the development of the nation has been at a very slow pace since independence, many studies attribute this to the poor state of leadership in the nation. The culture of corruption was extensively examined and it was revealed that the followers contribute greatly to the corrupting influence of the leaders.

\section{Conclusion}

Leadership styles are the approaches often adopted for use by leaders when given a leadership role to play in any organization. The use of the leadership styles and strategies is to motivate followers. Leadership is not a "one size fits all" phenomenon but should be applied using the prevailing situation. The study concluded then the null hypothesis that stated that, there is no significant relationship between leadership styles and strategies adopted in Nigeria and service delivery considered to be crucial to the Nigerian citizens in the $21^{\text {st }}$ century is hereby rejected and the alternative hypothesis that, there is a significant relationship between leadership styles and strategies adopted in Nigeria and service delivery considered to be crucial to the Nigerian citizens in the $21^{\text {st }}$ century. Also, the second null hypothesis that stated that, there is no significant relationship between leadership styles and strategies (autocratic, laissez -faire, democratic, transactional and transformational) and economic wellbeing of the Nigerian citizens in the $21^{\text {st }}$ century is hereby rejected and the alternative hypothesis that, there is a significant relationship between leadership styles and strategies (autocratic, laissez -faire, democratic, transactional and transformational) and the Economic wellbeing of the Nigerian citizens in the $21^{\text {st }}$ century. Leadership styles and strategies should be used to fit organizations, situations, groups, and individuals as the case may be. It is thus useful to possess a thorough understanding of the different styles as such knowledge increases the tools available to lead effectively in achieving set goals in an organization.

\section{Recommendations}

In the light of the above study, the following recommendations were made as follows: 
a. Government should from time to time organize leadership seminars and workshops for leaders at all levels both in the public and private sectors with a view of educating them (workers, management and other stakeholders) of various organizations on the proper applications of relevant leadership styles and strategies in this $21^{\text {st }}$ century. These will enable the organizations achieve their objective of ensuring that they deliver services earmarked for citizens in Nigeria.

b. It is essentially for government to ensure that they organize leadership training and retraining for leaders on guiding diverse followers, with different groups and ideologies. They must be prepared to manage each group with a style of leadership that will get them to deliver for their organization. Also, the ability of leaders to master the minds of their followers and influence them appropriately would be necessary for the advancement of Nigeria. This will close the gap between the leaders and their subjects leading to the creation of Economic wellbeing of all the citizens in the $21^{\text {st }}$ century in Nigeria.

\section{References}

Adutoju, T. (2011). Presidential leadership styles: implications and imperatives. https://www.linkedin.com/pulse/presidental-leadership-implications-tayo-aduloju.

Adedamola, A. F. (2016). An investigation into the impact of leadership styles on employees' retention: identifying which leadership style best encourages employee's retention in the Nigerian banking sector: a case study of Zenith bank plc, Nigeria. https://expertscolum.com/content/concept-leadership Retrieved on January 11

Adair, I. (2003). Not bosses but leaders: how to lead the way to success (3rd Ed.). London. Kogan Page.

Armstrong, M. (2012). Armstrong's handbook on management and leadership: developing effective people skills for better leadership and management: $3^{\text {rd }}$ Ed. London. Kogan Page.

Anyamele, S. C. (2004). Institutional management in higher education: a study of leadership approaches to quality improvement in university management, Nigerian and finnish cases. doctoral dissertation, university of Helsinki: E-Thesis. Retrieved September 232014 from http://ethesis.helsinki.fi.julkaisut/kay/uk/anyamele/institut.pdf

Anderson, R. C. (1959). Leaning in discussions: A resume of the authoritarian democratic studies. Harvard Educational Review, 29, 201-212.

Awolio, B. J., Walumbwa, F. O., \& Weber, T. J. (2009). Leadership: current theories, research and future directions: Annual Review of Psychology, 60(2009), 421-449. https://doi.org/10.1146/annurev.psych.60.110707.163621

Barret, D. J. (n.d). Leadership communications: a communication approach for senior level managers. $\quad$ Retrieved $\quad$ March 2014 from: http"//scholarship.rice.edu/bitstream/handle/1911/27037/Leadership\%20Communication\%20 -20A\%20Communication\%20Approach\%20for20Senioe-Level\%20Managers\%20-\%Barret.p df. 
Bass, B., \& Bass, R. (2008). The bass handbook of leadership: theory, research and managerial Application. New York: Simon and Schuster.

Beare, H., Caldwell, B., \& Milikan, R. (1997). Dimensions of leadership. In Megan Crawford, L. Kudd \& riches, C. (ed). Leadership and teams in educational management: Buckingham and Philadelphia. Open University Press.

Bell, R. M. (2013). Charismatic leadership: case study with Ronald Reagan as exemplar: Emerging Leadership Journeys, 6(1), 66-74.

Boulding. (1956). The image: knowledge in life and society. Ann Arbor, MI. University of Michigan Press. https://doi.org/10.3998/mpub.6607

Charry, K. (2012). Leadership theories - 8 Major leadership theories: Retrieved March 23, 2014 from http://psychology.about.com/od/leadership/p/theory.htm.

Chaudhry, A. Q., \& Javed, H. (2012). Impact of transactional and laissez faire leadership style on motivation. International Journal of Business and Social Sciences, 3(7), 258-264.

Cherry, K. (2011). What is a Theory. Retrieved March 19, 2014 from https://psyschology.about.com/od/tindex/f/theory.gtm

Chukwu, B., \& Eluka, J. (2013). Applications of leadership theories in Nigerian business organizations: European Journal of Business and Management, 5(15).

Goodnight, F. (2011). Laissez faire leadership: encyclopedia of leadership: London. UK. Sage Publications.

Gwavuya, F. (2001). Leadership influences on turnover intentions of academic staff in tertiary institutions in Zimbabwe: Journal of Academic Leadership, 9(1), 10-20.

Greenstein, F. I. (2005). Presidents: their styles and their leadership. Center for public leadership. https://hdl.handle.net/1721.1/55942.

Hargreaves, A., \& Fink, D. (2004). The seven principles of sustainable leadership. Educational Leadership, 61(7), 1-12.

Hargreaves, A., \& Goodson. (2006). Educational change over time: the sustainability and non-sustainability of three decades of secondary school change and continuity. Educational Administration Quarterly Journal, 42(1), 3-41. https://doi.org/10.1177/0013161X05277975

Harkman, M. Z., \& Johnson, C. E. (1996). Leadership a communication perspective ( $2^{\text {nd }}$ ed.) Prospect Heights, IL Waveland Press.

Ibara, E. C. (2010). Perspectives in educational administration: Port Harcourt. Nigeria. Rodi Printing and Publishing.

Jenkins, T. (2013). Reflections on Kenneth E. Boulding's the image: glimpsing the roots of peace education pedagogy: Journal of Peace Education and Social Justice, 7(1), 27-37.

Ivancevich, J., Konopaste, R., \& Matteson, M. (2007) Organizational behaviour and 
management: New York. McGraw-Hill Irwin.

Nneoma, A. B., Ajike, E. O., Akinlabi, B. H., \& Kabuoh, M. N. (2014). The influence of Nigerian culture on leadership and its implication on the sustainable development of the national: International Policy Brief Series - Education and Science Journal, 4(1).

Nwagboso, C. I., \& Duke, O. (2012). Nigeria and the challenges of leadership in the $21^{\text {st }}$ century: a critique. International Journal of Humanities and Social Sciences, 2(13).

Lamb, L. F., \& McKee, K. B. (2004). Applied public cases in stakeholder management: Mahwah, New Jersey. Lawrence Erlbaum Associates. Routledge. https://doi.org/10.4324/9781410611208

Lamb, R. (2013). How can managers use participative leadership effectively: Retrieved March 17, 2014 from https://www.task.fm/participative-leadership

Lewis, P. S., Goodman, S. H., \& Fandt, P. (1995). Management: challenges in the $21^{\text {st }}$ century: New York. West Publishing.

Lewin, K., Lippitt, R., \& White, R. K. (1939). Patterns of aggressive behavior in experimentally created "social climates". The Journal of social psychology, 10(2), 269-299. https://doi.org/10.1080/00224545.1939.9713366

Mulford, L. J. (2002). School leaders: changing roles and impact on teacher and school Effectiveness: A Paper Commissioned by the Education and Training Policy Division, OECD for the Activity Attracting, Developing and Retaining Effective Teachers. April, 2003.

Mullins, L. J. (2000). Management and organizational behavior: London. Pitman Publishers.

Naylor, J. (1999). Management. Harlow, England. Prentice Hall.

Northouse, G. (2007). Leadership theory and practice: $\left(3^{\text {rd }}\right.$ ed.) Thousand Oak Sage Publications.

Ololube, N. P. (2012). Sociology of education and society: an interactive approach: Owerri. Nigeria. Springfield Publishers.

Ololube, N. P. (2013). Educational management, planning and supervision. model for effective Implementation: Owerri. Nigeria. Springfield Publishers.

Ololube, N. P., Dufada, U. J., Uriah, O. A., \& Agbor, C. N. (2013). Education for development: impediments to the globalization of higher education in Nigeria: International Journal of Educational Foundations and Management, 9(2), 109-130.

Ololube, N. P., Egbezor, D. E., Kpolovie, P. J., \& Amaele, S. (2012). Theoretical debates on school effectiveness research: lessons for third world education development agendas: In Ololube, N. P., \& Kpolovie, P. J (eds.). Educational management in developing economies: cases 'n'school effectiveness and quality improvement Saarbrucken: Lambert Publishers.

Peretomode, V. F. (1991). Educational administration: applied concept and theoretical Perspective: Lagos. Nigeria, Joja Educational Research and Publishers. 
Rowe, W. G. (2007). Cases in leadership: Thousand Oaks. CA: Sage Publications.

Santrock, J. W. (2007). A topical approach to life-span development: New York. NY McGraw-Hill.

Schaefer, R. T. (2005). Sociology. (9 ${ }^{\text {th }}$ ed). New York NY. McGraw-Hill.

Schoderbek, P. P., Cosier, R. A., \& Aplin, J. C. (1988). Management: San Diego. USA. Harcourt Brace Jovanovich Publishers.

Tayo, A. (2015). Presidential leadership styles: implications and imperatives. Nigeria.

Toolkit (n.d). Leadership styles: choosing the right style for the situation: Retrieved January 12, 2014 from https://www.mindtools.com/pages/article/newLDR_84.htm

United States Army (1983). Military leadership (FM 22-100). Washington, DC,. US Government Printing Office.

Wallace, M., \& Hoyle, E. (2005). Towards effective management of a reformed teaching profession. Paper Presented at the $4^{\text {th }}$ Seminar of the ESRC Teaching and Learning Research Programme Thematic Seminar Series 'Changing Teachers' Roles, Identities and Professionalism' King's College. London, $5^{\text {th }}$ July 2005.

Wakabi, B. M. (2016). Leadership style and staff retention in organizations: International Journal of Science and Research, 5(1). Pp. 412-416. International Journal of Science and Research. https://doi.org/10.21275/v5i1.NOV152642

Weddle, J. (2013). Levels of decision making in the workplace. Retrieved March 13, 2014 from http://www.jobdig.com/articles/1115/Levels_of_Decision_Making_in_the_Workplace.html

Wolinski, S. (2010). Leadership theories. Retrieved from June 14, 2014 from https://managementhelp.org/blogs/leadership/201004/21/leadership-theories

\section{Appendix 1}

Department of Public Administration,

Faculty of Arts and Social Sciences,

Gombe State University,

Gombe. Nigeria.

matthewfbello@gmail.com

Dear Respondent, we are conducting a research on "Knitting the Web of Leadership Styles and Strategies on Service Delivery and Economic Wellbeing of Citizens in the Nigerian Fourth Republic". Your responses and views are highly important in achieving the objectives of this study. The information provided will be treated as private and confidential and will be 


\section{Macrothink

used for the purpose of this study only.

Thank you for your valuable time, attention and cooperation.

Yours Faithfully,

\section{Matthew Funsho Bello}

(Researcher)

\section{Instruction}

\section{QUESTIONNAIRE}

This form is designed to generate data for analysis in this study. You are required to answer the questions by ticking one of the boxes provided against each question, the one that best describe your opinion

\section{SECTION A: PERSONAL DATA OF RESPONDENTS}

1. Educational qualification:
(a) School Certificate
(b) Diploma
(c) B.Sc./HND
(d) M.Sc. and Others

2. Duration of Service: (a) 1 - 5 years

(b) 5 - 10 years

(c) 10 years and above

3. Sex: (a) Male

(b) Female

4. Age: (a) $18-26$ years

(b) $26-33$ years

(c) 34-41 years

(d) 42 years and above

5. What is your Federal Ministry?

6. Cadre:

(a) Management Staff

(b) Senior Staff

(c) Junior Staff $\mid$ Casual Staff

\section{SECTION B}

You are required to answer the following question by ticking on the option provided. Note the following: where SA = Strongly Agreed (4), A = Agreed (3), SD = Strongly Disagreed (2) D= Disagreed (1) 


\section{Macrothink}

\begin{tabular}{|l|l|c|c|c|c|}
\hline & \multicolumn{1}{|c|}{ President Olusegun Obasanjo (1999-2007) } & SA & A & SD & D \\
\hline 5 & \multicolumn{1}{|c|}{$\begin{array}{l}\text { The Leadership Styles and Strategies adopted then were } \\
\text { capable to manage the multifarious array of Stakeholders } \\
\text { and existing Political interest? }\end{array}$} & 4 & 3 & 2 & 1 \\
\hline 6 & $\begin{array}{l}\text { The presidential Leadership Styles and Strategies adopted } \\
\text { created a good working relationship between the working } \\
\text { team, cabinet, Federal Legislatures and Judiciary? }\end{array}$ & & & \\
\hline 7 & $\begin{array}{l}\text { The Presidential Leadership Styles and Strategies adopted } \\
\text { brought with it Strength to the task of good Governance? }\end{array}$ & & & \\
\hline 8. & $\begin{array}{l}\text { The Presidential Leadership Styles and Strategies adopted } \\
\text { brought with it Weakness to the task of good Governance? }\end{array}$ & & & \\
\hline
\end{tabular}

\section{Presidential Leadership Styles and Strategies in Nigeria from 2007-2010}

\begin{tabular}{|l|l|c|c|c|c|}
\hline & \multicolumn{1}{|c|}{ President Umoru Musa Yar'Adua (2007-2010) } & SA & A & SD & D \\
\hline 9 & $\begin{array}{l}\text { The Leadership Styles and Strategies adopted then were } \\
\text { capable to manage the multifarious array of Stakeholders } \\
\text { and existing Political interest? }\end{array}$ & 4 & 3 & 2 & 1 \\
\hline 10 & $\begin{array}{l}\text { The presidential Leadership Styles and Strategies adopted } \\
\text { created a good working relationship between the working } \\
\text { team, carbinate, Federal Legislatures and Judiciary? }\end{array}$ & & & \\
\hline 11 & $\begin{array}{l}\text { The Presidential Leadership Styles and Strategies adopted } \\
\text { brought with it Strength to the task of good Governance? }\end{array}$ & & & \\
\hline 12 & $\begin{array}{l}\text { The Presidential Leadership Styles and Strategies adopted } \\
\text { brought with it Weakness to the task of good Governance? }\end{array}$ & $\begin{array}{l}\text { The Leadership Styles and Strategies adopted then were } \\
\text { capable to manage the multifarious array of Stakeholders } \\
\text { and existing Political interest? }\end{array}$ & & & \\
\hline 13 & & & \\
\hline
\end{tabular}

\section{Presidential Leadership Styles and Strategies in Nigeria from 2010-2015}

\begin{tabular}{|l|l|c|c|c|c|}
\hline & \multicolumn{1}{|c|}{ President Goodluck Jonathan (2010-2015) } & SA & A & SD & D \\
\hline 14 & $\begin{array}{l}\text { The Leadership Styles and Strategies adopted then were } \\
\text { capable to manage the multifarious array of Stakeholders } \\
\text { and existing Political interest? }\end{array}$ & 4 & 3 & 2 & 1 \\
\hline 15 & $\begin{array}{l}\text { The presidential Leadership Styles and Strategies adopted } \\
\text { created a good working relationship between the working } \\
\text { team, carbinate, Federal Legislatures and Judiciary? }\end{array}$ & & & \\
\hline 16 & $\begin{array}{l}\text { The Presidential Leadership Styles and Strategies adopted } \\
\text { brought with it Strength to the task of good Governance? }\end{array}$ & & & \\
\hline 17 & $\begin{array}{l}\text { The Presidential Leadership Styles and Strategies adopted } \\
\text { brought with it Weakness to the task of good Governance? }\end{array}$ & & & \\
\hline
\end{tabular}


Presidential Leadership Styles and Strategies in Nigeria from 2015-Date Related questions

\begin{tabular}{|c|l|l|l|l|l|}
\hline 18 & $\begin{array}{l}\text { President Muhammed Buhari (2015-Date) } \\
\text { The Leadership Styles and Strategies adopted then were } \\
\text { capable to manage the multifarious array of Stakeholders and } \\
\text { existing Political interest? }\end{array}$ & 4 & 3 & 2 & 1 \\
\hline 19 & $\begin{array}{l}\text { The presidential Leadership Styles and Strategies adopted } \\
\text { created a good working relationship between the working } \\
\text { team, carbinate, Federal Legislatures and Judiciary? }\end{array}$ & $\begin{array}{l}\text { The Presidential Leadership Styles and Strategies adopted } \\
\text { brought with it Strength to the task of good Governance? }\end{array}$ & & & \\
\hline 21 & $\begin{array}{l}\text { The Presidential Leadership Styles and Strategies adopted } \\
\text { brought with it Weakness to the task of good Governance? }\end{array}$ & & & \\
\hline
\end{tabular}

Impact Of Service Delivery (Public Sector Institutions On Citizens)

\begin{tabular}{|l|l|l|l|l|l|}
\hline & \multicolumn{1}{|c|}{ President Olusegun Obasanjo (1999-2007) } & SA & A & SD & D \\
\hline 22 & $\begin{array}{l}\text { The Presidential Leadership Styles and Strategies adopted } \\
\text { has led to improvement in the quality of Purchase of } \\
\text { Goods provided? }\end{array}$ & 4 & 3 & 2 & 1 \\
\hline 23 & $\begin{array}{l}\text { The Government Policies put in place has enhanced } \\
\text { citizens Satisfaction on the Quality of Services Rendered? }\end{array}$ & & & \\
\hline 24 & $\begin{array}{l}\text { The Presidential Leadership Styles and Strategies adopted } \\
\text { has influenced the Effectiveness of Service Delivery } \\
\text { Process to Citizens? }\end{array}$ & $\begin{array}{l}\text { The Presidential Leadership Styles and Strategies adopted } \\
\text { has influences Citizens Service Attitudes and Behaviors as } \\
\text { well as the interrelationship between these constructs and } \\
\text { Managerial Service Delivery Inputs? }\end{array}$ & & \\
\hline
\end{tabular}

Impact of Service Delivery (Public Sector Institutions) on Citizens

\begin{tabular}{|l|l|c|c|c|c|}
\hline & \multicolumn{1}{|c|}{ President Umoru Musa Yar'Adua (2007-2010) } & SA & A & SD & D \\
\hline 26 & $\begin{array}{l}\text { The Presidential Leadership Styles and Strategies adopted } \\
\text { has led to improvement in the quality of Purchase of } \\
\text { Goods provided? }\end{array}$ & 4 & 3 & 2 & 1 \\
\hline 27 & $\begin{array}{l}\text { The Government Policies put in place has enhanced } \\
\text { citizens Satisfaction on the Quality of Services Rendered? }\end{array}$ & & & \\
\hline 28 & $\begin{array}{l}\text { The Presidential Leadership Styles and Strategies adopted } \\
\text { has influenced the Effectiveness of Service Delivery } \\
\text { Process to Citizens? }\end{array}$ & & & \\
\hline 29 & $\begin{array}{l}\text { The Presidential Leadership Styles and Strategies adopted } \\
\text { The }\end{array}$ & & & \\
\hline
\end{tabular}




\begin{tabular}{|c|c|}
\hline & $\begin{array}{l}\text { has influences Citizens Service Attitudes and Behaviors as } \\
\text { well as the interrelationship between these constructs and } \\
\text { Managerial Service Delivery Inputs? }\end{array}$ \\
\hline 30 & $\begin{array}{l}\text { The Presidential Leadership Styles and Strategies adopted } \\
\text { has led to improvement in the quality of Purchase of } \\
\text { Goods provided? }\end{array}$ \\
\hline
\end{tabular}

Impact of Service Delivery (Public Sector Institutions on Citizens) Related questions

\begin{tabular}{|l|l|c|c|c|c|}
\hline & \multicolumn{1}{|c|}{ President Goodluck Jonathan (2010-2015) } & SA & A & SD & D \\
\hline 31 & $\begin{array}{l}\text { The Presidential Leadership Styles and Strategies adopted } \\
\text { has led to improvement in the quality of Purchase of } \\
\text { Goods provided? }\end{array}$ & 4 & 3 & 2 & 1 \\
\hline 32 & $\begin{array}{l}\text { The Government Policies put in place has enhanced } \\
\text { citizens Satisfaction on the Quality of Services Rendered? }\end{array}$ & & & \\
\hline 33 & $\begin{array}{l}\text { The Presidential Leadership Styles and Strategies adopted } \\
\text { has influenced the Effectiveness of Service Delivery } \\
\text { Process to Citizens? }\end{array}$ & $\begin{array}{l}\text { The Presidential Leadership Styles and Strategies adopted } \\
\text { has influences Citizens Service Attitudes and Behaviors as } \\
\text { well as the interrelationship between these constructs and } \\
\text { Managerial Service Delivery Inputs? }\end{array}$ & & & \\
\hline 34 & & & \\
\hline
\end{tabular}

Impact of Service Delivery (Public Sector Institutions on Citizens) Related questions

\begin{tabular}{|l|l|l|l|l|l|}
\hline & \multicolumn{1}{|c|}{ President Muhammed Buhari SA } & A & SD & D \\
\hline 35 & $\begin{array}{l}\text { The Presidential Leadership Styles and Strategies adopted } \\
\text { has led to improvement in the quality of Purchase of } \\
\text { Goods provided? }\end{array}$ & 4 & 3 & 2 & 1 \\
\hline 36 & $\begin{array}{l}\text { The Government Policies put in place has enhanced } \\
\text { citizens Satisfaction on the Quality of Services Rendered? }\end{array}$ & & & \\
\hline 37 & $\begin{array}{l}\text { The Presidential Leadership Styles and Strategies adopted } \\
\text { has influenced the Effectiveness of Service Delivery } \\
\text { Process to Citizens? }\end{array}$ & $\begin{array}{l}\text { (20) } \\
\text { has influences Citizens Service Attitudes and Behaviors as } \\
\text { well as the interrelationship between these constructs and } \\
\text { Managerial Service Delivery Inputs? }\end{array}$ & & & \\
\hline 38. & \begin{tabular}{l} 
The Presidential Leadership Styles and Strategies adopted \\
\hline
\end{tabular}
\end{tabular}

IMPACT OF ECONOMIC WELLBEING (PUBLIC SECTOR INSTITUTIONS ON CITIZENS) 


\section{Macrothink}

\begin{tabular}{|l|l|c|c|c|c|}
\hline & \multicolumn{1}{|c|}{ President Olusegun Obasanjo (1999-2007) } & SA & A & SD & D \\
\hline 39 & $\begin{array}{l}\text { The Presidential Leadership Styles and Strategies adopted } \\
\text { has led to the Development of Human Capital in Nigeria }\end{array}$ & 4 & 3 & 2 & 1 \\
\hline 40 & $\begin{array}{l}\text { The Presidential Leadership Styles and Strategies adopted } \\
\text { has positively increased Literacy Ratio in Nigeria? }\end{array}$ & & & \\
\hline 41 & $\begin{array}{l}\text { The Presidential Leadership Styles and Strategies adopted } \\
\text { has improved the Quality and Quantity of important } \\
\text { Infrastructure in Nigeria? }\end{array}$ & $\begin{array}{l}\text { The Presidential Leadership Styles and Strategies adopted } \\
\text { has brought improvement in the Health and Safety Service } \\
\text { Delivery in Nigeria? }\end{array}$ & & & \\
\hline 42 & & & \\
\hline
\end{tabular}

Impact of Economic Wellbeing (Public Sector Institutions on Citizens) Related Questions

\begin{tabular}{|l|l|c|c|c|c|}
\hline & \multicolumn{1}{|c|}{ President Umoru Musa Yar'Adua (2007-2010) } & SA & A & SD & D \\
\hline 43 & $\begin{array}{l}\text { The Presidential Leadership Styles and Strategies adopted } \\
\text { has led to the Development of Human Capital in Nigeria }\end{array}$ & 4 & 3 & 2 & 1 \\
\hline 44 & $\begin{array}{l}\text { The Presidential Leadership Styles and Strategies adopted } \\
\text { has positively increased Literacy Ratio in Nigeria? }\end{array}$ & & & \\
\hline 45 & $\begin{array}{l}\text { The Presidential Leadership Styles and Strategies adopted } \\
\text { has improved the Quality and Quantity of important } \\
\text { Infrastructure in Nigeria? }\end{array}$ & $\begin{array}{l}\text { The Presidential Leadership Styles and Strategies adopted } \\
\text { has brought improvement in the Health and Safety Service } \\
\text { Delivery in Nigeria? }\end{array}$ & & & \\
\hline 46 & & & \\
\hline
\end{tabular}

Impact of Economic Wellbeing (Public Sector Institutions on Citizens) Related Questions

\begin{tabular}{|l|l|c|c|c|c|}
\hline & \multicolumn{1}{|c|}{ President Goodluck Jonathan (2010-2015) } & SA & A & SD & D \\
\hline 1 & $\begin{array}{l}\text { The Presidential Leadership Styles and Strategies adopted } \\
\text { has led to the Development of Human Capital in Nigeria }\end{array}$ & 4 & 3 & 2 & 1 \\
\hline 2 & $\begin{array}{l}\text { The Presidential Leadership Styles and Strategies adopted } \\
\text { has positively increased Literacy Ratio in Nigeria? }\end{array}$ & & & \\
\hline 3 & $\begin{array}{l}\text { The Presidential Leadership Styles and Strategies adopted } \\
\text { has improved the Quality and Quantity of important } \\
\text { Infrastructure in Nigeria? }\end{array}$ & $\begin{array}{l}\text { The Presidential Leadership Styles and Strategies adopted } \\
\text { has brought improvement in the Health and Safety Service } \\
\text { Delivery in Nigeria? }\end{array}$ & & & \\
\hline 3
\end{tabular}


Impact of Economic Wellbeing (Public Sector Institutions on Citizens)

\begin{tabular}{|l|l|c|c|c|c|}
\hline & \multicolumn{1}{|c|}{ President Muhammed Buhari (2015-Date) } & SA & A & SD & D \\
\hline 4 & $\begin{array}{l}\text { The Presidential Leadership Styles and Strategies adopted } \\
\text { has led to the Development of Human Capital in Nigeria }\end{array}$ & 4 & 3 & 2 & 1 \\
\hline 5 & $\begin{array}{l}\text { The Presidential Leadership Styles and Strategies adopted } \\
\text { has positively increased Literacy Ratio in Nigeria? }\end{array}$ & & & \\
\hline 6 & $\begin{array}{l}\text { The Presidential Leadership Styles and Strategies adopted } \\
\text { has improved the Quality and Quantity of important } \\
\text { Infrastructure in Nigeria? }\end{array}$ & $\begin{array}{l}\text { The Presidential Leadership Styles and Strategies adopted } \\
\text { has brought improvement in the Health and Safety Service } \\
\text { Delivery in Nigeria? }\end{array}$ & & & \\
\hline
\end{tabular}

\section{Copyright Disclaimer}

Copyright for this article is retained by the author(s), with first publication rights granted to the journal.

This is an open-access article distributed under the terms and conditions of the Creative Commons Attribution license (http://creativecommons.org/licenses/by/4.0/). 